\author{
s \\ Códices. \\ Los antiguos libros \\ del nuevo mundo \\ de M iguel León-Portilla \\ M éxico, Aguilar, 2003, \\ $335 \mathrm{pp}$., ilustraciones. \\ por \\ MARÍA ELENA BRISEÑO
}

M iguel León-Portilla, en su más reciente publicación, Códices Los antiguos libros del nuevo mundo, valora los códices mesoamericanos prehispánicos y coloniales como verdaderas enciclopedias, fuentes primarias imprescindibles para acercarse a nuestro pasado prehispánico y también como extraordinarias obras de arte, por lo que emprende su estudio a partir de la relación entre la palabra y la pintura, relación que explica con lo que él llama el "binomio ora lidad-pintura".

El ejercicio historiográfico que realiza León-Portilla en la primera parte del libro lo lleva a plantearse "nuevas preguntas" que le permitan la cabal comprensión de su objeto de estudio para proponer nuevas lecturas. En la introducción y en los primeros ca- pítulos, se pregunta: ¿qué representaba el libro para el habitante de M esoamérica? ¿Cómo se efectuaba la lectura de sus contenidos? ¿C uáles eran sus significados? ¿C uál fue el impacto de la Conquista en esos libros? León-Portilla basará su estudio y propuesta en el binomio oralidad-pintura, que en su opinión permitió preservar y comunicar los conocimientos que llegaron a tener los hombres y mujeres prehispánicos; "así lo expresó un antiguo tlahtolmatini, 'el sabio de la palabra': 'en los libros de pinturas están vuestros cantos', los trazos multicolores y los cantos, las plegarias, los discursos y los relatos".

León-Portilla introduce y sitúa la producción de estos libros, lleva a cabo una revisión de los diferentes tipos de acercamientos a los códices, desde el momento de la Conquista hasta nuestros días, y expone la relación oralidad-pintura en ellos para proponer la lectura de seis páginas de seis códices e invitarnos a desplegarlos y gozar del rico universo de la cultura del que son portadores. La tarea es muy ambiciosa, nos advierte, pero igual será la recompensa: acercarse con base firme a la historia y al saber que a través de muchos siglos dio vida a los pueblos de M esoamérica. T area y recompensa muy gratas, agregaríamos, por la belleza de estos códices.

En M esoamérica se desarrollaron complejos cómputos calendáricos y sistemas de 
DOI: http://dx.doi.org/10.22201/iie.18703062e.2002.81.2131

\section{I76 LIBROS}

escritura y se elaboraron libros. El libro, amoxtli, es el producto del arte del tlahcuilo - el ah ts'ib para el ámbito maya-, "el pintor-escribano", y del tlamatini, "el sabio, el maestro", "el dueño de la tinta negra, la tinta roja, el que tiene los libros, el que los guarda...", tlileh, tlapaleh, amuxhuah, amoxeh. I Para los antiguos mexicanos, leer y contemplar el libro era enterarse a través de imágenes, textos glíficos y la palabra de quienes los leían, que amplificaba de muchas maneras, con un lenguaje rico en me táforas, lo que se había propuesto transmitir. Se leía, nos dice M iguel León-Portilla, con o gracias a la palabra hablada y a la pintura que se ve, que se mira, en una relación oral-pictórica indisoluble.

El amoxtli guardaba relación con el palacio, la estera, el sitial, el linaje y el poder: era indispensable en la administración y en la reafirmación de la autoridad de los tlahtoque, e imprescindible era la consulta del tonalámatl, el libro de los destinos y de los días con el cual llevaban a cabo los registros calendáricos y astronómicos, interpretaban sus destinos y seguían sus complejos rituales; en sus libros se hablaba de los dioses y las formas de adorarlos y otras muchas cosas más. También para los macehualtin, el pue blo, tenían importancia porque en las fiestas, al son de los tambores, el huéhuetl y el teponaztli, y las flautas, se cantaba lo que se leía en los libros. León-Portilla nos dice que también existían el cuicámatl, "libro de los cantos", y el temicámatl, "libros de los sue ños", y otros que evocaban "la antigua palabra", la huehuehtlahtolli.

En los primeros años después de la Conquista se quemaron y destruyeron los libros y las bibliotecas, como durante la que

I. Códice Florentino, vol. I, libro III, f. 39 r. ma que protagonizó fray D iego de Landa en Yucatán y la destrucción de la biblioteca de Tezcoco: sólo is códices prehispánicos sobreviven. Pero el gran número de libros coIoniales existentes - cerca de soo- representa el intento de resarcir la pérdida; así, el antiguo tlahcuiloyan, "el lugar donde se escribe y se pinta", se transformó en el scriptorium donde los tlahcuiloque, pintores-escribanos, pintan el Códice M endoza por encomienda del virrey Antonio de M endoza, quien quería informar a Carlos $V$ sobre la historia y la cultura de los mexicanos; donde se escriben textos en náhuatl, maya, quiché y otras lenguas, redactados con alfabeto - el Popol Vuh, Los anales de T latelolco-; donde se elaboran libros con pinturas y con textos en castellano y náhuatl como el Códice Florentino de fray Bernardino de Sahagún y sus informantes del Colegio Imperial de Santa C ruz de T latelolco, "extraordinario experimento en el encuentro de culturas". Ahí se formaron grupos trilingües porque hablaban náhuatl, castellano y latín y se emprendió el rescate de la antigua tradición indígena, como la transcripción de cuarenta huehuehtlahtolli, testimonios de la antigua palabra.

Para responder a sus preguntas sobre la significación y empleo de los códices, LeónPortilla propone acercarse a ellos tomando en cuenta el binomio oralidad-pintura, en cada uno de los diferentes contextos espacio-temporales, el ámbito nahua, mixteco y maya durante la época prehispánica y el siglo xvi. "Yo canto las pinturas del libro", canta un poeta náhuatl anónimo para resaltar la potencialidad semántica de la oralidad, las pinturas y los signos glíficos, que León-Portilla compara con la potencialidad de lectura de nuestros cd-rom como soportes de almacenamiento, preservación, trans- 
misión, intercomunicación y difusión de conocimientos, además de permitir muchas posibles lecturas.

Sobre los códices elaborados ya bajo el dominio español, León-Portilla advierte, críticamente, que son producto del trasvase de la oralidad, las pinturas y los signos glíficos a un soporte tan distinto como el de la escritura alfabética. "Luminosa prisión del alfabeto", llamó Ángel M aría Garibay a ese sistema de imágenes y sonidos que tuvo que ser alterado por la escritura lineal alfabética, como en la Historia tolteca-chichimeca y los códices T lotzin, Q uinantzin y Xólotl, por citar algunos de los ejemplos nombrados por León-Portilla y en los cuales aparecen pinturas y glifos acompañados de textos escritos con el alfabeto, muchos de ellos en lengua indígena y representaciones glíficas de nombres de lugar y de persona acompañados de "transliteraciones" alfabéticas. Para LeónPortilla estos códices son "documentos mestizos" en los cuales es patente el proceso del paso de la antigua tradición pictoglífica a esa luminosa prisión del alfabeto.

León-Portilla aconseja no olvidar el binomio oralidad-pintura para realizar modernas "lecturas" de los códices, sin dejar de relacionarlos con los textos indígenas recogidos por tradición oral, y observar evidencias externas como el registro alfabético y la aparición de tradiciones paralelas en las diferentes lenguas y culturas mesoamericanas y sus nexos con objetos o monumentos arqueológicos. También hay que atender las evidencias internas de la coherencia estructural, estilística y semántica del texto en cuestión, en función de la cual podrá valorarse su pertenencia 0 no al tejido cultural indígena. En este punto, León-Portilla se detiene para explicar los procesos de hermenéutica crítica y los problemas que se susci- tan cuando se hacen lo que él Ilama "lecturas líricas", de las cuales presenta ejemplos.

Para responder a la pregunta iquiénes son los investigadores cuyos enfoques y contribuciones han influido más en nuestras pesquisas contemporáneas?, León-Portilla revisa diversos acercamientos a los códices desde los primeros años después de la conquista hasta los estudios contemporáneos más recientes. Se detiene en "cuatro grandes momentos" en que se hicieron importantes aportaciones al conocimiento de los contenidos de libros con los investigadores Alfonso Caso, Karl Antón N owotny, J. Eric S. Thompson y Yuri Valentinovich Knorosov. $N$ os ofrece una muy erudita relación de estudios y estudiosos que se ve enriquecida por las fichas bibliográficas presentadas en los pies de página, por la reseña de las colecciones Kingsborough, Graz y Fondo de Cultura Económica y por la de los catálogos de códices existentes que incluye en un apéndice. D ice León-Portilla que no podría mencionar los nombres de todos los que han ingresado en los últimos años en este campo de estudio "y es de esperarse que el número habrá de acrecentarse".

D espués de presentado su objeto, esto es, los códices, y revisado lo que se ha dicho de ellos, León-Portilla llega a su propósito original: revelarnos las potencialidades semánticas de los códices a través de la lectura de una página de cada uno de los siguientes seis códices: la primera lámina del Tonalámatl de los Pochtecas (Códice Fejérváry-M ayer), el tonal pohualli de la lámina 4 del Códice Borbónico, el Xoconochco de la lámina 25 de la M atrícula de Tributos, el folio 46r del Códice Telleriano-Remense, la lámina 74 del Códice M aya de D resde y la 48 del códice mixteco conocido como Vindobonensis M exicanus I. H ay que destacar la extraordi- 
DOI: http://dx.doi.org/10.22201/iie.18703062e.2002.81.2131

I 78

naria calidad de las ilustraciones con que León-Portilla apoya su propuesta.

Para la lectura de cada lámina, LeónPortilla da los datos generales del manuscrito (procedencia, lugar donde se encuentra, descripción física, semejanzas con otros manuscritos, posible referencia con fuentes escritas, etc.). Para abordar los contenidos semánticos ofrece explicaciones sobre el tema 0 asunto del códice (el espacio y el calendario en el caso del Tonalámatl, aspectos económicos, administrativos y tributarios en cuanto a la M atrícula, aspectos históricos como la "Gue rra del M ixtón" respecto al Telleriano-Re mense, el registro calendárico astrológico y metereológico del códice maya e información genealógica relativos al códice mixteco). D espués, procede a describir todas las figuras que se pueden observar en la página, tratando de leer explicando, en lo posible, su significación en el contexto de la página de forma integral, lo que incluye asignar valores semánticos al color.

Con una "invitación más que conclusión", puesto que mucho queda aún por investigar en torno a los códices, León-Portilla termina su libro. Para los que nos ha interesado el estudio de estos manuscritos, Códices. Los antiguos libros de nuevo mundo - además de proponer una forma de acercamiento basada en el binomio oralidadpintura- representa el punto medio entre los estudios generales de difusión y los estudios especializados. Para los interesados en el estudio de nuestro pasado prehispánico, se ratifica su importancia como fuentes insoslayables. Para el lector no especializado, es una lectura muy placentera, interesante e ilustrativa. Para todos, es un regalo, generoso, de la vida de estudio, análisis y reflexión de M iguel León-Portilla dedicada a la palabra en el M éxico antiguo.
Con una alusión a estos libros en un poema náhuatl, León-Portilla cierra su obra. El poema que cita concibe al supremo $\mathrm{Da}$ dor de la vida como un tlahcuilo, porque cuanto existe en la tierra, en realidad, dice, está pintado e inscrito en un amoxtli, porque el mundo está pintado y sólo existe en su portentoso libro:
Con flores, D ador de la vida
Con cantos das color,
Con canto sombreas
A los que han de vivir en la tierra.
D espués pondrás fin a águilas y tigres.
Sólo en tu libro de pinturas vivimos
Aquí sobre la tierra. ${ }^{2}$

\section{Estudio, devoción y belleza. 0 bras selectas de la pinacoteca universi taria. Si gl os $\boldsymbol{x} \mathbb{V} \mathbb{I} \boldsymbol{x}-\boldsymbol{x} \boldsymbol{x}$ de Eduardo M erlo y Velia M orales}

M éxico, Benemérita U niversidad Autónoma de Puebla, 2002.

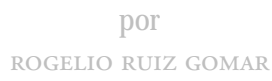

Como se señala desde el subtítulo, el núcleo principal del libro que nos ocupa tiene el propósito de ofrecer una selección de la rica colección de pintura que forma parte del patrimonio artístico que guarda la Benemé

2. Del manuscrito de los Romances de los señores de N ueva España, f. 35 r. 